\title{
VIOLÊNCIA INSTITUCIONAL CONTRA A MULHER: O PODER JUDICIÁRIO, DE PRETENSO PROTETOR A EFETIVO AGRESSOR
}

\author{
INSTITUTIONAL VIOLENCE AGAINST WOMEN: THE JUDICIARY POWER, \\ FROM PRETENSO PROTECTOR TO AGRESSOR EFFECTIVE
}

\author{
VIOLENCIA INSTITUCIONAL CONTRA LA MUJER: EL PODER JUDICIAL, DE \\ PRETENSO PROTECTOR A AGRESOR
}

\section{Cássius Guimarães Chal}

http://orcid.org/0000-0001-5893-3901 / http://lattes.cnpq.br/7954290513228454 / cassiuschai@gmail.com

Estudos Doutorais e de pós.doutorado em Derecho Administrativo de la Sociedad del Conocimiento - Universidad de Salamanca. Professor Titular da Escola Superior do Ministério Público do Maranhão (ESMPMA). Professor Adjunto III da Universidade Federal do Maranhão, Curso de Graduação em Direito e titular do programa de pós-graduação em

Direito e Instituições do Sistema de Justiça. Membro-professor da International Association of Constitutional Law. São Luís, MA, Brasil.

\section{JÉssica Pereira dos Santos}

http://orcid.org/0000-0003-0288-2601 / http://lattes.cnpq.br/2306229668221519 / jessicasantos1905@gmail.com

Bacharelanda em Direito pela Universidade Federal do Maranhão (UFMA). Pesquisadora voluntária do Grupo de Pesquisa e Extensão. Cultura, Direito e Sociedade (DGP/CNPq/UFMA). Bolsista do PET Conexões de Saberes: Direitos Humanos, Culturas e Subjetividades (UFMA). São Luís, MA, Brasil

\section{Denisson Gonçalves Chaves}

http://orcid.org/0000-0003-2512-5347 / http://lattes.cnpq.br/9405450012585004 / denissongoncalves@gmail.com

Mestre em Direito e Instituições do Sistema de Justiça pela Universidade Federal do Maranhão (PPGDIR/UFMA). Pesquisador Voluntário do Grupo de Ensino Pesquisa e Extensão: Cultura, Direito e Sociedade (2010-2017). Professor Substituto na área de Direito Público na Universidade Federal do Maranhão - Campus Imperatriz (UFMA). São Luís, MA, Brasil.

\begin{abstract}
RESUMO
No Brasil tornaram-se crescentes os estudos relacionados ao gênero, em especial, após o advento da Lei 11.340/2006. No entanto, ainda são poucas as pesquisas e os estudos debruçados à violência institucional praticada contra a mulher, especialmente no Estado do Maranhão. O presente trabalho objetivou analisar a violência institucional como uma forma recentemente publicizada de violência contra a mulher, tornando-se uma barreira para um atendimento efetivo das mulheres em situação de violência doméstica e familiar. Procedeu-se abordagem de revisão bibliográfica e em seguida, aplicação de ferramenta de investigação quanti-qualitativa com a aplicação de 35 questionários com jurisdicinadas (usuárias) da Vara Especial de Combate à Violência Doméstica e Familiar Contra a Mulher de São LuísMA. Verificou-se um sentimento de frustração das mulheres que buscam o atendimento jurisdicional, evidenciando-se que a violência institucional obstaculariza um acesso digno à Justiça e uma inefetividade de determinação judicial justa, condizente com o que as vítimas necessitam.
\end{abstract}

Palavras-chave: Atendimento Judiciário; Direitos Humanos; Violência Doméstica e Familiar; Violência Institucional. 


\section{ABSTRACT}

In Brazil, studies related to gender have been increasing, especially after the Federal Act $n^{\circ}$. 11.340/2006 entered into force. However, related to so-called institutional violence practiced against women researches and studies are very unrepresentative, especially in the State of Maranhão. The present study aimed to analyze institutional violence as a recently publicized form of violence against women, becoming a barrier to effective caring of women in situations of domestic and family violence. A bibliographic study was carried out, and 35 questionnaires were then applied to users (litigation victims parties) of the Special Court to Fight Domestic and Family Violence Against Women in São Luís-MA. It was verified a sense of frustration among women seeking judicial assistance, showing that institutional violence hinders access to decent justice and a just granted judicial determination, consistent with what the victimized women need.

Keywords: Legal Assistance; Human Rights; Domestic and Family Violence; Institutional Violence.

\section{RESUMEN}

En Brasil se ha vuelto creciente los estudios relacionados con la violencia de género, en especial, después de la vigencia de la Ley $11.340 / 2006$. Sin embargo, todavía son pocas las investigaciones y los estudios en lo que se refiere a la violencia institucional contra la mujer, especialmente en el Estado de Maranhão. El presente trabajo objetivó analizar la violencia institucional como una forma concreta de violencia praticada contra la mujer bajo el formalismo jurídico, convirtiéndose en una barrera para una atención efectiva de las mujeres en situación de violencia doméstica y familiar. Para tanto, se realizó una revisión bibliográfica con posterior aplicación de herramientas cualitativas con aplicaciones de 35 ensayos encuestas dirigidos a mujeres víctimas que buscarán la atención y protección jurisdiccional, evidenciándose que la violencia institucional restringe un acceso efectivo a la justicia digna y una de ellas, una determinación judicial justa, conforme a lo que las jurisdiccionales necesitan.

Palabras clave: Asistencia Judicial; Derechos humanos; Violencia Doméstica y Familiar; Violencia Institucional.

\section{SUMÁRIO}

INTRODUÇAO; 1 GÊNERO E VIOLÊNCIA: TIPOLOGIAS DAS VIOLAÇÕES; 2 VIOLÊNCIA INSTITUCIONAL: QUANDO O ESTADO AGRIDE A MULHER; 3 "A VOZ (VEZ) DAS VÍTIMAS”: O ATENDIMENTO NA VARA ESPECIAL DE COMBATE À VIOLÊNCIA DOMÉSTICA E FAMILIAR DE SÃO LUÍS/MA E A PERCEPÇÃO DAS JURISDICIONADAS ACERCA DOS SERVIÇOS PÚBLICOS; CONCLUSÃO; REFERÊNCIAS.

\section{INTRODUÇÃO}

A Lei $n^{\circ} 11.340 / 2006$ - Lei Maria da Penha - sancionada em 07 de agosto de 2006 representa um importante progresso no que tange aos direitos das mulheres e um marco das lutas feministas no Brasil, sendo reconhecida pelas Nações Unidas como uma das legislações mais avançadas do mundo no tratamento dessa matéria.

Apesar do avanço que essa legislação representa para o país, sua aplicação tem ocorrido em contextos sociais e políticos adversos, o que significa que ainda permanecem muitos obstáculos para o acesso das mulheres à Justiça, sendo um destes a Violência Institucional.

A violência institucional contra a mulher é aquela praticada, por ação ou omissão, nas instituições públicas ou privadas prestadoras de serviços, como por exemplo, o Judiciário. Essa espécie de violência é consumada por agentes que deveriam prestar uma atenção humanizada, preventiva e reparadora de danos. 
No Brasil tornou-se crescente os estudos relacionados ao gênero, em especial, após o advento da Lei $11.340 / 2006$. No entanto, ainda são poucas as pesquisas no que dizem respeito à violência institucional contra a mulher, especialmente no estado do Maranhão.

Dessa forma, o problema em análise, é como a violência institucional reproduz novas formas de violência contra a mulher no âmbito do Poder Judiciário da cidade de São Luís-MA. Observando-se a maneira como esse atendimento é ofertado e a percepção das jurisdicionadas acerca do serviço oferecido.

O presente trabalho objetivou analisar a violência institucional como uma forma recentemente publicizada de violência contra a mulher, tornando-se uma barreira para um atendimento efetivo das mulheres em situação de violência doméstica e familiar que buscam atendimento na Vara Especial de Combate à Violência Doméstica e Familiar de São Luís-MA.

O caminho da pesquisa apresenta o estudo bibliográfico acerca de gênero e violência doméstica e familiar contra a mulher. Em seguida, houve a coleta de dados na Vara Especial de Combate à Violência Doméstica e Familiar Contra a Mulher de São Luís-MA, na ocasião foram aplicados 35 questionários ${ }^{1}$. De acordo com o Comitê de Ética em Pesquisa envolvendo Seres Humanos decidiu-se nomear as entrevistadas por $(01,02,03 \ldots)$ a fim de preservar sua identidade.

Em um primeiro momento foi realizada uma construção teórica do conceito de gênero e das diferentes expressões da violência de gênero até então classificadas. Por conseguinte, foram apresentados o conceito de violência institucional e suas principais formas de atuação, qualificando essa espécie de violência como violadora dos Direitos Humanos na perspectiva do gênero. E, por fim, demonstra-se a percepção das jurisdicionadas acerca dos serviços públicos, com ênfase no Judiciário.

\section{GÊNERO E VIOLÊNCIA: TIPOLOGIAS DAS VIOLAÇÕES}

\footnotetext{
1 Pesquisa de campo realizada em Novembro de 2016. Importante destacar que nesta época havia apenas uma Vara Especial de Combate à Violência Doméstica e Familiar Contra a Mulher em São Luís-MA. Em 14/11/17 foi inaugurada a Casa da Mulher Brasileira em São Luís-MA. A Casa da Mulher Brasileira funciona 24 horas por dia, integrando diversos serviços de atendimento especializado às mulheres, como triagem e acolhimento, apoio psicossocial, delegacias, entre outros. Em 10/04/18 a $2^{\text {a }}$ Vara de Combate à Violência Doméstica e Familiar passou a funcionar na Casa da Mulher Brasileira, de forma a otimizar o atendimento prestado às mulheres em situação de violência. A unidade é responsável por processar e julgar as medidas protetivas de urgência em favor das mulheres, previstas na Lei Maria da Penha.
} 
Historicamente homens e mulheres ocupam lugares distintos na sociedade, esta desigualdade é consequência de uma construção social, seletiva que por intermédio da divisão sexual de papéis, estabeleceu que mulheres e homens atuem em campos distintos. Neste cenário, os homens, por sua vez, ocupam posições de maior relevância na sociedade. Isso, como resultado, institui uma organização social de gênero hierarquizada, com preponderância masculina, que na maioria das vezes, vem acompanhada da violência. Sobre a divisão sexual dos papéis, explicam Saffioti e Almeida:

Embora não se comungue das explicações baseadas na lógica da complementaridade, da perspectiva da falocracia, a mulher deve complementar o homem, isto é, desempenhar os papéis sociais que ele recusa para si próprio. Em outros termos, ela deve atingir, no máximo, a penumbra, quando não consegue se limitar à sombra. ${ }^{2}$

A palavra gênero é empregada como uma maneira de referir-se à organização social das relações entre os sexos. Joan Scott descreve gênero como sendo "um elemento constitutivo de relações sociais baseado nas diferenças percebidas entre o sexo, o gênero é uma forma primeira de significar as relações de poder". ${ }^{3}$ Desta maneira, a autora remete sua discussão, para além do binômio homem/mulher, masculino/feminino, demonstrando assim, que gênero está relacionado com os símbolos culturais, as normas, a organização estatal e a subjetividade ${ }^{4}$, afirmando que estes elementos estão correlacionados entre si. $^{5}$

Para além desta percepção, Judith Butler, ao contrário do que argumentavam as teorias feministas da sua época, ressalta em seus estudos que o gênero seria um fenômeno volátil e contextual, que não evidenciaria um ser substantivo, "mas um ponto relativo de convergência entre conjuntos específicos de relações, cultural e historicamente convergentes". ${ }^{6}$ Nessa

\footnotetext{
2 SAFFIOTI, Heleieth I. B.; ALMEIDA, Suely Souza de. Violência de gênero: poder e impotência. Rio de Janeiro: Revinter, 1995, p. 15.

${ }^{3}$ SCOTT, Joan. Gênero: uma categoria útil para análise histórica. Tradução: Christine Rufino Dabat; Maria Betânia Ávila. Texto original: Joan Scott - Gender: auseful category of historical analyses. Gender and the politics of history. New York: Columbia University Press, 1989, p. 21.

${ }^{4}$ Os símbolos culturais são aqueles que se expressam através de imagens, músicas, lendas passadas de geração a geração, tradições; e as normas são aquelas previstas através das leis, dos códigos e das constituições; a organização está relacionada às estruturas do poder estatal, dos sistemas educacionais, econômicos e religiosos, por meio dos quais são postas em práticas os valores e as normas e por fim a subjetividade que é a formação das identidades e que se referem ao que sucede com as pessoas desde o seu nascimento. PORTELLA, A. P.; GOUVEIA, T. Ideias e dinâmicas para trabalhar com gênero. Recife: SOS Corpo, Gênero e Cidadania, 1999, pp. 245-249.

${ }^{5}$ SCOTT, Joan. Gênero: uma categoria útil para análise histórica. Tradução: Christine Rufino Dabat; Maria Betânia Ávila. Texto original: Joan Scott - Gender: auseful category of historical analyses. Gender and the politics of history. New York: Columbia University Press, 1989, p. 21.

${ }^{6}$ BUTLER, Judith. Problemas de gênero: Feminismo e subversão da identidade. Rio de Janeiro: Civilização Brasileira, 2010, p. 29.
} 
acepção, o gênero não deve ser restringido ao biológico e sim ser entendido como uma construção social. O gênero, assim considerado, “[...] não é nem o resultado causal do sexo, nem tampouco tão aparentemente fixo quanto o sexo. Assim, a unidade do sujeito já é potencialmente contestada pela distinção que abre espaço ao gênero como interpretação múltipla do sexo". ${ }^{7}$

Portanto, gênero está associado à maneira de ser dos homens e das mulheres na sociedade e às relações que estabelecem entre si em todos os campos da vida. 0 gênero pode ser assim percebido como um conceito sociopolítico válido para a análise das sociedades e para detectar a realidade das mulheres. Dessa forma:

Ao determinar lugares aos homens e interditá-los às mulheres, a sociedade cria formas de exclusão que se consubstanciam em processos que terão marcas profundas na cidadania feminina; seus reflexos aparecem na desigualdade de representação legislativa e em praticamente todos os espaços de decisão e poder que vão do Judiciário ao Executivo, das direções sindicais e partidárias aos cargos nas universidades, entre outros. ${ }^{8}$

A violência de gênero consiste em uma maneira de manifestação da desigualdade de gênero, que não ocorre de forma aleatória, pois é decorrente de uma organização social que privilegia o masculino em função do feminino, tanto no âmbito público como no privado.

Essa espécie de violência se constitui em formas de opressão e de insensibilidade nas relações entre homens e mulheres, estruturalmente constituídas, reproduzidas no dia a dia e na maioria das vezes sofridas pelas mulheres. Essa natureza de violência se expõe como um meio de dominação e existe entre todas as raças, etnias, classe social e faixas etárias. Sua demonstração maior é o machismo naturalizado na sociedade. Segundo Almeida:

As desigualdades de gênero fundam-se e fecundam-se a partir da matriz hegemônica de gênero. Isto é, de concepções dominantes de feminilidade e masculinidade, que vão se configurando a partir de disputas simbólicas e materiais, processadas, dentro de outros espaços, nas instituições cuja funcionalidade no processo de reprodução social é inconteste - marcadamente, a família, a escola, a igreja, os meios de comunicação - e materializadas, ainda, nas relações de trabalho, no quadro político-partidário, nas relações sindicais e na divisão sexual do trabalho operada nas diversas esferas da vida social, inclusive nas distintas organizações da sociedade civil. É nesses espaços e práticas que vão se produzindo, reatualizando e naturalizando hierarquias, mecanismos de subordinação, o acesso desigual às fontes de poder e aos bens materiais e simbólicos. É também nesse registro que vai se consolidando, para a

\footnotetext{
${ }^{7}$ BUTLER, Judith. Problemas de gênero: Feminismo e subversão da identidade. Rio de Janeiro: Civilização Brasileira, 2010, p. 24.

${ }^{8}$ FERREIRA, Maria Mary. Representação feminina e construção da democracia no Brasil. Coimbra: CES, 2004. Disponível em: <http://www.ces.uc.pt/lab2004/inscricao/pdfs/painel29/MAryFerreira.pdf>. Acesso em: 29 jan. 2017, p. 03.
} 
mulher, a jornada extensiva de trabalho, a maior superposição de tempos e espaços nas dimensões pública e privada da vida, as menores possibilidades de investimento em qualificação, as maiores cobranças quanto à sua responsabilidade na reprodução familiar. ${ }^{9}$

Bourdieu observa que a unidade doméstica é um dos espaços em que a dominação masculina se manifesta de maneira mais indiscutível (e não só através do recurso à violência física). Além do mais, o princípio da perpetuação das relações de força materiais e simbólicas que aí são exercidas se coloca essencialmente fora desta unidade, em instâncias como a Igreja, a Escola ou o Estado, em suas ações propriamente políticas, declaradas ou escondidas, oficiais ou oficiosas. ${ }^{10}$

No Brasil, a violência contra a mulher é um problema crítico e contumaz ${ }^{11}$ que está arraigado na prática da sociedade como herança secular de um ideário patriarcal de incapacidade e submissão da mulher. ${ }^{12}$ Afirmação que se comprova, por exemplo, pelas estatísticas do Disque Denúncia da Secretaria de Políticas para as Mulheres da Presidência da República (SPM-PR), o qual recebeu cerca de 67.962 denúncias apenas no primeiro semestre do ano de 2016. Em comparação com o mesmo período do ano passado, verificou-se um aumento de $133 \%$ nos relatos referentes à violência doméstica e familiar. ${ }^{13}$

As expressões violência doméstica, violência familiar e violência contra a mulher normalmente são usadas como equivalentes à violência de gênero, no entanto, cada um destes termos possui significados e consequências teóricas e práticas distintas. Dessa maneira, violência contra a mulher, de acordo com Almeida ${ }^{14}$ enfatiza o alvo contra o qual a violência é dirigida, sendo que o termo não indica um sujeito, mas apenas um objeto, demonstrando o lugar da

${ }^{9}$ ALMEIDA, Suely Souza de. (Org.). Violência de gênero e políticas públicas. Rio de Janeiro: UFRJ, 2007, p. 27.

${ }^{10}$ BOURDIEU, Pierre. A dominação masculina. Rio de Janeiro: Bertrand Brasil, 2011, p. 138.

11 Entre 1980 e 2013, 106.093 brasileiras foram vítimas de assassinato. De 2003 a 2013, o número de vítimas do sexo feminino cresceu de 3.937 para 4.762, ou seja, mais de $21 \%$ na década. WAISELFISZ, Julio Jacobo. Mapa da Violência 2015: Homicídio de mulheres no Brasil. Brasília: Secretaria Especial de Políticas para as Mulheres, 2015, pp. 11-13. Disponível em: <https://www.mapadaviolencia.org.br/pdf2015/MapaViolencia_2015_mulheres.pdf>. Acesso em $03 \mathrm{fev}$. 2017.

120 conceito de patriarcado reporta-se à dominação-exploração das mulheres pelos homens, relação hierárquica esta que invade todos os espaços da vida social. É o conceito que evidencia especificamente a sujeição da mulher. SAFFIOTI, Heleieth I. B. Gênero, patriarcado, violência. São Paulo: Fundação Perseu Abramo, 2004, p. 44.

${ }^{13}$ Os dados são da Seretaria de Políticas para as Mulheres da Presidência da República (SPM-PR), a partir de balanços dos relatos recebidos pelo Ligue 180. BRASIL. Ministério da Justiça e Cidadania. Balanço Ligue 180. Brasília: Secretaria de Política para as Mulheres, 2016, p. 03. Disponível em: <http://www.spm.gov.br/balanco180_2016-3.pdf>. Acesso em: 12 nov. 2016.

${ }^{14}$ ALMEIDA, Suely Souza de. (Org.). Violência de gênero e políticas públicas. Rio de Janeiro: UFRJ, 2007, p. 30. 
vítima e sugerindo unilateralidade do ato, evidenciando a mulher como vítima preferencial dessa modalidade de violência.

A violência familiar é aquela que "envolve membros de uma mesma família extensa ou nuclear, levando-se em conta a consanguinidade e a afinidade" ${ }^{15}$, podendo ocorrer no interior do domicílio ou fora dele. Já a violência doméstica é entendida como aquela "que é própria à esfera privada. Atinge, porém, também pessoas que, não pertencendo à família, vivem, parcial ou integralmente, no domicílio do agressor, como é o caso de agregadas(os) e empregadas(os) domésticas(os)". ${ }^{16}$

$\mathrm{Na}$ Lei $\mathrm{n}^{\circ}$ 11.340/2006, o legislador optou pela expressão "violência doméstica e familiar”, compreendendo-a como uma espécie de violência de gênero, definindo-a assim, como:

Art. $5^{\circ}-[\ldots]$ qualquer ação ou omissão baseada no gênero que the cause morte, lesão, sofrimento físico, sexual ou psicológico e dano moral o patrimonial: I - no âmbito da unidade doméstica, compreendida como o espaço de convívio permanente de pessoas, com ou sem vínculo familiar, inclusive as esporadicamente agregadas; II - no âmbito da família, compreendida como a comunidade formada por indivíduos que são ou se consideram aparentados, unidos por laços naturais, por afinidade ou por vontade expressa; III - em qualquer relação íntima, de afeto, na qual o agressor conviva ou tenha convivido com a ofendida, independentemente de coabitação. ${ }^{17}$

Dessa forma, observa-se que o conceito de violência doméstica e familiar trabalhado na Lei Maria da Penha, tem finalidade pedagógica, buscando simplificar a compreensão desse fenômeno. Nesse caso, o intérprete deve estar ciente dos fins sociais a que a lei se destina, sendo eles: a prevenção e a coibição da violência doméstica e familiar contra a mulher e a proteção da mulher em situação de violência. Evidenciando dessa forma, que a violência doméstica e familiar contra a mulher consiste em violação dos Direito Humanos.

\footnotetext{
${ }^{15}$ SAFFIOTI, Heleieth I. B. Já se mete a colher em briga de marido e mulher. São Paulo em Perspectiva. A violência disseminada. São Paulo, vol. 13, n. 04, out./dez. 1999, p. 83. Disponível em: <http://www.scielo.br/scielo.php?pid=S0102-88391999000400009\&script=sci_arttext>. Acesso em: 21 dez. 2016.

${ }^{16}$ SAFFIOTI, Heleieth I. B. Gênero, patriarcado, violência. São Paulo: Fundação Perseu Abramo, 2004, p. 71.

17 BRASIL. Lei n. 11.340, de 07 de agosto de 2006. Cria mecanismos para coibir a violência doméstica e familiar contra a mulher, nos termos do $\S 8^{\circ}$ do art. 226 da Constituição Federal, da Convenção sobre a Eliminação de Todas as Formas de Discriminação contra as Mulheres e da Convenção Interamericana para Prevenir, Punir e Erradicar a Violência contra a Mulher; dispõe sobre a criação dos Juizados de Violência Doméstica e Familiar contra a Mulher; altera o Código de Processo Penal, o Código Penal e a Lei de Execução Penal; e dá outras providências. Diário Oficial da União: Poder Legislativo, Brasília, DF. Disponível em: <http://www.planalto.gov.br/ccivil_03/_ato2004-2006/2006/lei//11340.htm>. Acesso em: 10 nov. 2016.
} 


\section{VIOLÊNCIA INSTITUCIONAL: QUANDO O ESTADO AGRIDE A MULHER}

No âmbito da violência de gênero, as desigualdades biológicas fortalecem um estado de acesso desigual a direitos e de submissão a um modelo histórico de violações cotidianas que carecem de uma luta de resistência e combate.

Nesse contexto, é extremamente importante a análise do conteúdo dos discursos jurídicos, de modo a verificar as formas de perpetuação da dominação masculina dentro desses sistemas. Segundo Bourdieu:

Essa evocação do conjunto de instâncias que contribuem para reproduzir a hierarquia dos gêneros deveria permitir esboçar o programa de uma análise histórica do que permanece e do que se transformou naquelas instâncias; análise esta, que por si só pode fornecer instrumentos indispensáveis à compreensão tanto daquilo que podemos constatar ter, não raro de forma surpreendente, permanecido constante na condição das mulheres (e isto sem precisar invocar a resistência e a má vontade masculina ou a responsabilidade das próprias mulheres), quanto as mudanças visíveis ou invisíveis que tal condição experimentou em período recente. ${ }^{18}$

Ainda que se tenham introduzido novos padrões legislativos e interpretativos, percebese a persistência de uma práxis jurídica que causa incômodo pela desconsideração de um recorte de gênero no trato institucional da violência doméstica. Observa-se assim, que:

Nosso direito é masculino, condicionado em seu conteúdo por interesse masculino e modo de sentir masculino (especialmente no direito da família), mas masculino, sobretudo, em sua interpretação e sua aplicação, uma aplicação puramente racional e prática de disposições genéricas duras, diante das quais o indivíduo e seu sentimento não contam. Por isso, quis-se excluir as mulheres, também para o futuro, da participação ativa na jurisdição. ${ }^{19}$

A persistência da não garantia efetiva de direitos às mulheres tem como uma das causas a falta de um atendimento específico à sua demanda. Dessa maneira, criaram-se as delegacias de defesa da mulher que representaram, até recentemente, “[...] principal senão única política pública de prevenção e combate à violência contra as mulheres". ${ }^{20}$ Todavia, não houve um comprometimento por parte do sistema judicial para uma prestação jurisdicional precisa que assegurasse a proteção das vítimas ao denunciarem e, tampouco, com a transformação da

\footnotetext{
${ }^{18}$ BOURDIEU, Pierre. A dominação masculina. Rio de Janeiro: Bertrand Brasil, 2011, p. 105.

${ }_{19}$ RADBRUCH, Gustav. Introdução à Ciência do Direito. São Paulo: Martins Fontes, 1999, pp.146-147.

${ }^{20}$ MASSULA, Letícia. A violência e o acesso das mulheres à justiça: o caminho das pedras ou as pedras do (no) caminho. In: Vinte e cinco anos de respostas brasileiras em violência contra a mulher: alcances e limites. São Paulo: Coletivo Feminista Sexualidade e Saúde, 2006, p. 149.
} 
realidade social dessa mulher que está em situação de violência doméstica e familiar. De acordo com a autora:

Outro problema enfrentado pelas mulheres é a insuficiência de políticas públicas e serviços para o atendimento da demanda. O Brasil possui 5.560 municípios, 268 DEAMs e 71 casas-abrigo; ou seja, a demanda reprimida desses serviços é muito grande, e pode ser observada no dia-a-dia dos atendimentos. São inúmeros os relatos da falta desse serviço, por parte de ONGs que realizam o atendimento direto. Quando este existe, constantemente faltam vagas para o atendimento dos casos. Ou seja, é a concretização do "tem, mas está em falta!". ${ }^{21}$

Ademais, quando as denúncias chegavam aos tribunais, os julgamentos demoravam muito, tanto pela falta de prioridade quanto pela própria morosidade do sistema. Com isso, a mulher muitas vezes continua sob um ambiente de abusos e violências, sendo maltratada e coagida a retirar sua denúncia e a manter-se calada, pois, se encontrava em uma situação de vulnerabilidade, uma vez que não se confia na eficácia do judiciário e na sensibilidade da polícia para encarregar-se desses casos. Esse sentimento é muito bem explicitado por Wolff e Waldow, quando observam que:

As mulheres, por sua vez, não ousam reclamar, mesmo desagradadas e sentindo dor e constrangimento, por medo, por vergonha e por se sentirem inferiorizadas perante uma suposta autoridade dos donos do saber; outras por constatarem serem as atitudes dos profissionais como parte do seu fazer e, portanto, supõem seja normal. Não parecem estar usufruindo de um direito, e sim de um favor. ${ }^{22}$

Mediante a luta por reconhecimento dos direitos das mulheres, como iguais destinatárias do Direito, evidenciando sua exclusão das garantias no espaço público e também no espaço privado; e reivindicando igual respeito e consideração. Emergiu, então, o debate em torno da negligência com relação à violência doméstica e familiar, junto à necessidade de um recorte de gênero para um atendimento especializado dos casos, assim como para a implementação de medidas que dessem assistência às mulheres agredidas, aos seus filhos(as) e ao próprio agressor.

A partir da responsabilização do Brasil pela Corte Interamericana de Direitos Humanos foi promulgada a Lei Maria da Penha (Lei 11.340/06). ${ }^{23}$ Por intermédio do seu advento enfatizou-

\footnotetext{
${ }^{21}$ MASSULA, Letícia. A violência e o acesso das mulheres à justiça: o caminho das pedras ou as pedras do (no) caminho. In: Vinte e cinco anos de respostas brasileiras em violência contra a mulher: alcances e limites. São Paulo: Coletivo Feminista Sexualidade e Saúde, 2006, p. 157.

22 WOLFF, L. R.; WALDOW, V. R. Violência consentida: mulheres em trabalho de parto e parto. Saúde e Sociedade, São Paulo, v. 17, n. 3, p. 138-151, set. 2008, p. 150.

${ }^{23}$ Caso 12.051. Maria da Penha Maia Fernandes, 04 abr. 2001. Em 20 de agosto de 1998, a Comissão Interamericana de Direitos Humanos recebeu uma denúncia apresentada pela Senhora Maria da Penha Maia Fernandes, pelo Centro pela Justiça e pelo Direito Internacional (CEJIL) e pelo Comitê Latino-
} 
se a magnitude da agressão às mulheres - concomitantemente incentivou-se o empoderamento ${ }^{24}$ e o sentimento de igualdade, tendo como base fundamental o reconhecimento do outro como sujeito de direito.

Como instituiu a Lei 11.340/06, em seus artigos 27 e 28, é compromisso do Estado brasileiro prover a assistência judiciária às mulheres vítimas de violência doméstica e familiar, definindo que:

Art. 27. Em todos os atos processuais, cíveis e criminais, a mulher em situação de violência doméstica e familiar deverá estar acompanhada de advogado, ressalvado o previsto no art. 19 desta Lei.

Art. 28. É garantido a toda mulher em situação de violência doméstica e familiar o acesso aos serviços de Defensoria Pública ou de Assistência Judiciária Gratuita, nos termos da lei, em sede policial e judicial, mediante atendimento específico e humanizado. ${ }^{25}$

No entanto, alguns estudos e pesquisas contemporâneas que argumentam sobre a aplicação da Lei Maria da Penha, têm observado a constância da banalização dos casos de violência contra a mulher, mostrando com isso, a relutância e reacomodação do sistema de justiça através de práticas que revitimizam a mulher e reproduzem estereótipos machistas. ${ }^{26}$ Esse déficit é gerado por diversas razões, dentre elas, ressalta-se: o despreparo no atendimento das vítimas de violência; a morosidade do sistema judicial; a falta de recursos e o medo da dissolução da família por parte da vítima. Segundo Massula:

Americano de Defesa dos Direitos da Mulher (CLADEM), baseada na competência que the conferem os artigos 44 e 46 da Convenção Americana sobre Direitos Humanos e o artigo 12 da Convenção Interamericana para Prevenir, Punir e Erradicar a Violência contra a Mulher (Convenção de Belém do Pará ou CVM). Disponível em: <http://www.cidh.org/annualrep/2000port/12051.htm>. Acesso em $18 \mathrm{dez}$. 2016.

24 Compreendido como, a alteração radical dos processos e estruturas que reduzem a posição de subordinada das mulheres como gênero. As mulheres tornam-se empoderadas através de tomadas de decisões coletivas e de mudanças individuais. 0 empoderamento das mulheres representa um desafio às relações patriarcais, significa uma mudança na dominação tradicional dos homens sobre as mulheres, garantindo-lhes autonomia. COSTA, Ana Alice. Gênero, poder e empoderamento das mulheres. Salvador: NEIM/UFBA, 1999, p. 07.

${ }^{25}$ BRASIL. Lei n. 11.340, de 07 de agosto de 2006. Cria mecanismos para coibir a violência doméstica e familiar contra a mulher, nos termos do $\$ 8^{\circ}$ do art. 226 da Constituição Federal, da Convenção sobre a Eliminação de Todas as Formas de Discriminação contra as Mulheres e da Convenção Interamericana para Prevenir, Punir e Erradicar a Violência contra a Mulher; dispõe sobre a criação dos Juizados de Violência Doméstica e Familiar contra a Mulher; altera o Código de Processo Penal, o Código Penal e a Lei de Execução Penal; e dá outras providências. Diário Oficial da União: Poder Legislativo, Brasília, DF. Disponível em: <http://www.planalto.gov.br/ccivil_03/_ato2004-2006/2006/lei/l11340.htm>. Acesso em: 10 nov. 2016.

${ }^{26}$ No Brasil o termo "revitimização" é muito utilizado no contexto jurídico, se referindo à situações em que a vítima de um tipo de violência passa por diversos profissionais, repetindo a sua história. 0 sofrimento ocasionado pela repetição desses fatos e os impactos causados a cada relato caracterizam o processo de revitimização. ANDREOTTI, C. Enfrentamento da revitimização: a escuta de crianças vítimas de violência sexual. São Paulo: Casa do Psicólogo, 2012, p. 66. 
A falta de pessoal capacitado e sensibilizado (Judiciário, polícia, defensorias públicas e casas-abrigo) para o atendimento de casos de violência contra as mulheres também é um fator que prejudica o acesso das mulheres agredidas à Justiça. Em muitos casos, a mulher levou meses, até anos, para ter coragem de se dirigir a um serviço de atendimento e denunciar o agressor. Se neste momento de extrema coragem ela não encontrar apoio, acolhimento e profissionais capacitados para atendê-la, acaba desistindo de levar a denúncia adiante. Infelizmente, grande parte dos profissionais que realizam atendimento de mulheres em situação de violência jamais passou por uma capacitação ou sensibilização sobre as especificidades que cercam o tema. Essa falta de preparo prejudica bastante $o$ atendimento, e em muitos casos acaba por revitimizar a mulher agredida - que, em lugar de apoio, encontra preconceito e uma visão esteriotipada de sua situação. ${ }^{27}$

Uma vez que a mulher - apesar de todos os empecilhos postos em destaque - decide procurar a assistência do Estado, além de sofrer com a situação de violência a qual foi exposta pode ainda sofrer um segundo tipo de violência: a institucional.

A violência institucional está diretamente relacionada aos Direitos Humanos, uma vez que sua prática é incompreensível perante uma sociedade que seja construída alicerçada nos valores de respeito à dignidade humana. Esse debate ainda é muito pouco publicizado nos diversos segmentos da sociedade, tanto na esfera dos usuários e usuárias quanto dos profissionais das distintas áreas dos serviços, sejam eles públicos ou privados. Tal violência fere o princípio da fraternidade, princípio este que rege as nossas ações no sentido de que devemos ser solidários em relação aos outros seres humanos.

É uma espécie de coerção que contribui na consolidação de uma ordem social injusta que precisa ser superada, pois é naturalizada dentro da sociedade e muita das vezes possui certa invisibilidade, não sendo compreendida como uma violação de direitos. Essa violência é praticada nas instituições prestadoras de serviços públicos ou privados e é cometida por profissionais que tem como função prestar um bom atendimento aos assistidos que procuram os serviços dessas instituições. ${ }^{28}$ É o que reafirma Taquette:

Violência Institucional é aquela praticada, por ação e/ou omissão, nas instituições prestadoras de serviços públicos tais como hospitais, postos de saúde, escolas, delegacias, Judiciário, dentre outras. É perpetrada por agentes que deveriam garantir uma atenção humanizada, preventiva e reparadora de danos. Na seara da violência institucional, podemos encontrar desde a dimensão mais ampla, como a falta de acesso aos serviços de saúde e a má qualidade dos

\footnotetext{
${ }^{27}$ MASSULA, Letícia. A violência e o acesso das mulheres à justiça: o caminho das pedras ou as pedras do (no) caminho. In: Vinte e cinco anos de respostas brasileiras em violência contra a mulher: alcances e limites. São Paulo: Coletivo Feminista Sexualidade e Saúde, 2006, p. 156.

28 AGENDE - Ações em Gênero e Cidadania e Desenvolvimento. 10 anos da adoção da Convenção Interamericana para Prevenir, Punir e Erradicar a Violência contra a Mulher / Convenção de Belém do Pará - AGENDE / Brasília, Junho de 2004, p. 11.
} 
serviços prestados, até mesmo como expressões mais sutis, mas não menos violentas, tais como os abusos cometidos em virtude das relações desiguais de poder entre profissional e usuário. Uma forma, infelizmente, muito comum de violência institucional ocorre em função de práticas discriminatórias, sendo as questões de gênero, raça, etnia, orientação sexual e religião um terreno fértil para a ocorrência de tal violência. A eliminação da violência institucional requer um grande esforço de todos nós, pois, em sua grande maioria, acontece em nossas práticas cotidianas com a população usuária dos serviços. ${ }^{29}$

Esta violência pode ser identificada de várias formas: peregrinação por diversos serviços até receber atendimento; falta de escuta, tempo, privacidade para os usuários(as); frieza, rispidez, falta de atenção, negligência; maus-tratos dos profissionais para com os usuários, motivados por discriminação, abrangendo as questões de raça, idade, opção sexual, gênero, deficiência física, doença mental; violação dos direitos reprodutivos (discriminação das mulheres em processo de abortamento, aceleração do parto para liberar leitos, preconceitos acerca dos papéis sexuais e em relação às mulheres soro positivas (HIV), quando estão grávidas (ou desejam engravidar); desqualificação do saber prático, da experiência de vida, diante do saber científico; tortura e violência física; banalização das necessidades e direitos dos usuários(as); críticas ou agressões a quem expressa desespero, diante da ausência de serviços que atenda a sua necessidade, ao invés de se promover uma aproximação e escuta atenciosa visando acalmar a pessoa e fornecer informações necessárias. ${ }^{30}$

A violência institucional nem sempre se revela como violência, passando muitas vezes despercebida, não pelo fato de ser menos cruel, mas pela forma sutil com que se expõe. Estes processos de dominação e de relação social podem estar tão arraigados na cultura que parecem até “naturais". É um fenômeno decorrente das relações de poder assimétricas e geradoras de desigualdades, presentes nas sociedades contemporâneas e integrados à cultura das relações sociais estabelecidas em algumas instituições, sejam elas públicas ou privadas.

Fundamental atentar para o fato de que, mesmo que se realizem todas as mudanças de ordem fisicoestrutural necessárias e programem-se soluções para a superação das falhas, melhoria de qualidade da organização e celeridade dos Juizados, existe a probabilidade da violência institucional persistir, se as práticas do Poder Judiciário não assumirem uma cultura jurídica feminista, ${ }^{31}$ promotora de transformações realmente substanciais. Pois,

29 TAQUETTE, Stella (org.). Mulher adolescente/jovem em situação de violência. Brasília: Secretaria Especial de Políticas para as Mulheres, 2007, p. 95.

30 BRASIL. Ministério da Saúde. Violência Intrafamiliar-Orientações para a Prática em Serviço/Cadernos de Atenção Básica - nº 08. Brasília - DF, 2003, pp. 21-22.

${ }^{31}$ Conjunto de orientações a valores e a interesses que configuram um padrão de atitudes face ao direito e aos direitos e face às instituições do Estado que produzem, aplicam, garantem ou violam o direito e os direitos. Nas sociedades contemporâneas, o Estado é um elemento central da cultura jurídica e nessa 
Ao observarmos o funcionamento das instituições que atuam nos procedimentos jurídicos dos casos de violência doméstica, percebemos alguns problemas estruturais e outros pontuais. Os Juizados Especiais de Violência Doméstica e Familiar contra a Mulher (JVDFMs) são os órgãos jurisdicionais responsáveis pela resolução dos casos de violência doméstica e, por consequência, pela aplicação da Lei Maria da Penha. Tais órgãos, entretanto, mostram-se de maneira hermética: fechados e confusos para a população em geral. Uma mulher que deseja romper a inércia de violência em que se encontra terá dificuldades em lidar com o sistema dos Juizados. ${ }^{32}$

Consequentemente, mais uma vez o Direito mostra-se masculino, inflexível e patriarcal. Nesse cenário, os valores feministas que preconizam a igualdade entre os gêneros, seriam pontuais ao se incorporarem às instituições jurisdicionais que tratam da violência doméstica.

Isso viabilizaria um tratamento especializado, humanizado e acolhedor às mulheres em situação de violência. Um tratamento que vislumbra não só à mera resolução de conflitos, mas que tenha por base um olhar crítico que se fundamente na igualdade e educação não-sexista, na desmistificação da violência e na deslegitimação dos meios que a justificam. Um tratamento que promova a mulher como detentora de direitos e que tenha por objetivo não só o fim da violência doméstica, mas sim o fim da cultura patriarcal que a legitima.

\section{3 “A VOZ (VEZ) DAS VÍTIMAS": O ATENDIMENTO NA VARA ESPECIAL DE COMBATE À VIOLÊNCIA DOMÉSTICA E FAMILIAR DE SÃO LUÍS/MA E A PERCEPÇÃO DAS JURISDICIONADAS ACERCA DOS SERVIÇOS PÚBLICOS}

A Vara Especial de Combate à Violência Doméstica e Familiar Contra a Mulher de São Luís foi criada em 07 de março de 2008, através da lei complementar 104/2006. ${ }^{33}$ Está situada no Fórum Desembargador Sarney Costa e atualmente conta com uma equipe multidisciplinar composta por uma juíza, um psicólogo e duas assistentes sociais.

medida a cultura jurídica é sempre cultura jurídico-política e não pode ser plenamente compreendida fora do âmbito mais amplo da cultura política. Por outro lado, a cultura jurídica reside nos cidadãos e suas organizações e, neste sentido, é também parte integrante da cultura de cidadania. SANTOS, B. S. Os Tribunais nas Sociedades Contemporâneas: o caso português, Porto: Afrontamento, 1996, p. 42.

32 BRASIL. Ministério da Justiça. Secretaria de Assuntos Legislativos. Violência contra a mulher e as práticas institucionais. Brasília: Ministério da Justiça, 2015, p. 52.

${ }^{33}$ Altera a redação dos arts. $6^{\circ}, 7^{\circ}, 9^{\circ}, 10,12,13$ e 77, $\S 1^{\circ}, 3^{\circ}$ e $5^{\circ}$, do art. 18 , §§ $1^{\circ}$ e $5^{\circ}$ do art. 22 e acrescenta dois parágrafos ao art. 42 da Lei Complementar $n^{\circ}$ 14, de 17 de dezembro de 1991 (Código de Divisão e Organização Judiciárias do Estado do Maranhão), e dá outras providências. Disponível em: <http://gerenciador.tjma.jus.br/app/webroot/files/publicacao/408272/aula_4_codigo_de_organizaooo_j udicioria_05032015_1814.pdf >. Acesso em: 11 jan. 2017. 
VIOLÊNCIA INSTITUCIONAL CONTRA A MULHER: O PODER JUDICIÁRIO, DE PRETENSO PROTETOR A EFETIVO AGRESSOR CÁSSIUS GUIMARÃES CHAI JÉSSICA PEREIRA DOS SANTOS DENISSON GONÇALVES CHAVES

$\mathrm{Na}$ coleta de dados, participaram 35 usuárias da Vara, número que corresponde a cerca de $6,8 \%$ dos atendimentos realizados em um semestre na instituição. ${ }^{34} \mathrm{~A}$ maioria das mulheres entrevistadas encontra-se na faixa etária de 30 a 39 anos (42\%), seguida de jovens de 18 a 29 $\operatorname{anos}(40 \%)$.

Em relação à profissão 17\% das entrevistadas são donas de casa, 11\% são professoras e 8,5\% são técnicas de enfermagem, ocupações que segundo Goffman, são destinadas às mulheres por meio dos genderismos institucionalizados, ${ }^{35}$ que se apresentam como mecanismos e estruturas que reproduzem e consolidam diariamente as diferenças de gênero, tornando-as suficientes para explicar as desigualdades sociais entre os homens e mulheres.

Os dados coletados demonstraram que as mulheres negras e índias são minorias na busca de um atendimento jurisdicional, somando apenas $22,8 \%$ das entrevistadas. De acordo com Mojab, "as mulheres negras sofrem uma dupla penalização, o sexismo e o racismo, elas estão na parte inferior da precarização das relações de produção". ${ }^{36}$

No que diz respeito à violência contra as mulheres, a associação entre gênero e raça pode, frequentemente, criar um cenário de sucessivas discriminações e violências que se exteriorizam tanto como fatores de aumento da vulnerabilidade, sobretudo para os grupos etários mais jovens, quanto em obstáculos que as mulheres negras enfrentam para denunciar as violências sofridas. Estes óbices, por sua vez, são efeitos do racismo institucional que restringe o acesso à Justiça para as mulheres, mas também refletem o descrédito dessa população com o funcionamento das instituições de segurança e justiça. ${ }^{37}$

34 Segundo os Dados estatísticos da Vara, foram realizados no primeiro semestre de 2015, 508 atendimentos. Disponível em: $<$ http://gerenciador.tjma.jus.br/app/webroot/files/publicacao/407035/dados_estatosticos_da_vara_espe cializada_da_comarca_de_soo_luos_-_ano_2016_15092016_1056.pdf>. Acesso em: 13 jan. 2017.

${ }_{35}$ Estes incluem, entre outros, a divisão dos banheiros em conformidade com o gênero institucionalizada nas sociedades ocidentais; a segregação do mercado do trabalho em função do gênero, assim como a maneira tradicional da escolha do parceiro, implicando em constelações de cônjuges quase sempre iguais (homem mais alto e mais velho com mulher mais baixa e mais jovem). Com essa escolha, assim argumenta Goffman, mulheres e homens criam a melhor base para demonstrarem mutuamente, de maneira eficiente e convincente, sua 'natureza' supostamente diferente. GOFFMANN, Erving. Das Arrangement der Geschlechter. Frankfurt/M., 1994 [1977], p. 143.

${ }^{36}$ MOJAB, Shahrzad (ED.). Marxism and Feminism.Zed Books London, 2015, p. 917.

$37 \mathrm{O}$ peso do racismo institucional sobre a decisão das mulheres negras em denunciar a violência doméstica foi evidenciado na pesquisa de vitimização realizada pelo IBGE em 2009: entre as mulheres que sofreram violência praticada pelo cônjuge/ex-cônjuge, 61,6\% das mulheres brancas acionaram o serviço policial, enquanto apenas $51,9 \%$ das mulheres negras tomaram esta decisão. As justificativas apresentadas referem ao medo de sofrer represálias ou à percepção de que a intervenção policial não era necessária, respostas que devem ser interpretadas no contexto mais amplo da experiência da população negra com as instituições policiais (mais derepressão que de proteção de direitos) e do racismo institucional que produz novas formas de vitimização. INSTITUTO DE PESQUISA ECONÔMICA APLICADA (IPEA). Retrato das 
Outro fator que merece destaque é o fato de $42 \%$ das entrevistadas possuírem ensino médio, $42 \%$ o ensino superior e $8,5 \%$ possuírem pós-graduação. Essa estatística aponta que as mulheres com baixa escolaridade possuem mais limitações no acesso ao Poder Judiciário, de acordo com Massula, "existe um desconhecimento real por parte da população acerca dos direitos de que é detentora". ${ }^{38}$ Esse desconhecimento obstaculiza o acesso à Justiça das mulheres, de maneira que não é possível reivindicar algo que se desconhece:

O desconhecimento das normas do Direito, dos ritos, dos formalismos processuais e legais compõe o quadro de dificuldades próprias do acesso à Justiça e de uma cultura jurídica popular que gera expectativas e concepções diversas do que venha a ser o justo. Daí a importância de informações judiciais e extrajudiciais de qualidade, buscando, inclusive, a prevenção de um conflito. Daí também a importância de uma Defensoria especializada e engajada na rede de proteção aos direitos da mulher. ${ }^{39}$

Além disso, 40\% das usuárias responderam que possuem uma renda de 02 a 05 salários mínimos. Isso demonstra que uma considerável parcela de mulheres abordadas possui recursos financeiros para requerer uma prestação judicial efetiva, que não dependa necessariamente do número insuficiente de defensores públicos. Tal dado enfatiza um dos principais desafios para o acesso à Justiça das mulheres, a "feminização da pobreza"40:

Como estão entre as mais pobres, também é maior o número de mulheres nãoconsumidoras e que, portanto, não usufruem da justiça-serviço. As mulheres brasileiras vivenciam, pois, no dia-a-dia, uma situação de desigualdade com os homens, que obstaculiza a fruição dos direitos de que são detentoras. 0 que vale dizer: ser mulher é ainda um fator de discriminação, que se reflete nas práticas sociais e institucionais, em especial no acesso à justiça. ${ }^{41}$

desigualdades de gênero e raça. Brasília: Ipea, 2011, p. 39 . Disponível em: <http://www.ipea.gov.br/retrato/pdf/revista.pdf>. Acesso em: 25 jan. 2017.

${ }^{38}$ MASSULA, Letícia. A violência e o acesso das mulheres à justiça: o caminho das pedras ou as pedras do (no) caminho. In: Vinte e cinco anos de respostas brasileiras em violência contra a mulher: alcances e limites. São Paulo: Coletivo Feminista Sexualidade e Saúde, 2006, p. 141.

39 BRASIL. Ministério da Justiça. Secretaria de Assuntos Legislativos. Violência contra a mulher e as práticas institucionais. Brasília: Ministério da Justiça, 2015, p. 55.

400 conceito 'feminização da pobreza' representa a idéia de que as mulheres vêm se tornando, ao longo do tempo, mais pobres do que os homens. De acordo com o Relatório do Desenvolvimento Humano 1995, "A pobreza tem o rosto de uma mulher - de 1.3 bilhão de pessoas na pobreza, $70 \%$ são mulheres." NOVELLINO, M. S. F. Os estudos sobre feminização da pobreza e políticas públicas para mulheres. In: XXVIII Encontro Anual da ANPOCS, 2004, Caxambu. XXVIIII Encontro Anual da ANPOCS, 2004. v. 1, p. 04. Disponível em: <https://www.anpocs.com/index.php/papers-28-encontro/st-5/st23-2/4076-mnovellinoos-estudos/file>. Acesso em: 10 jan. 2017.

${ }^{41}$ MASSULA, Letícia. A violência e o acesso das mulheres à justiça: o caminho das pedras ou as pedras do (no) caminho. In: Vinte e cinco anos de respostas brasileiras em violência contra a mulher: alcances e limites. São Paulo: Coletivo Feminista Sexualidade e Saúde, 2006, p. 144. 
Quando indagadas sobre o conhecimento da Violência Institucional, 65\% das jurisdicionadas afirmaram conhecer essa espécie de violação de direitos. Uma das usuárias relata que “É uma frustração pedir a ajuda do Judiciário, pois na mídia existem diversas campanhas para estimular a denúncia, mas na vida real nada do que é prometido funciona de forma efetiva [sic]". (Entrevistada 01)

De acordo com a Política Nacional de Enfrentamento à Violência Contra as Mulheres ${ }^{42}$ as campanhas que visibilizem as diferentes expressões de violência de gênero sofridas pelas mulheres e que rompam com a tolerância da sociedade frente ao fenômeno, consistem em uma das medidas do âmbito preventivo da violência contra a mulher. ${ }^{43}$ No entanto, o atendimento oferecido no cotidiano burocrático e o "padrão ritualístico processual frio e cartesiano", que não cabem nos conflitos de violência de gênero, muitos menos nos de âmbito familiar, acabam por frustrar a vítima que busca uma escuta sensível e humanizada na esperança da "solução para a vida". ${ }^{44}$

Apenas $14 \%$ das entrevistadas disseram nunca ter sofrido nenhuma das expressões da violência institucional e outros $20 \%$ das participantes responderam que não sabiam se já tinham passado por uma situação de violência dentro do Judiciário. Demonstrando-se assim, o caráter despercebido de tal violência e a necessidade de estratégias institucionais que se impliquem em reparar esses cenários de opressão às mulheres.

A Medida Protetiva de Urgência foi uma das inovações trazidas pela Lei Maria da Penha, em especial, no que tange ao tratamento dado à violência doméstica e familiar contra a mulher. Durante a pesquisa contatou-se que $68 \%$ das mulheres atendidas pela Vara solicitaram Medidas Protetivas de Urgência, no entanto apenas $11 \%$ das usuárias afirmaram que seus agressores cumprem tais medidas, que mesmo deferidas, parecem não encontrar qualquer tipo de sanção caso sejam descumpridas. Analisando esse mecanismo, Lima observa que:

As medidas protetivas não são instrumentos para assegurar processos. 0 fim das medidas protetivas é assegurar direitos fundamentais, evitando a continuidade da violência e das situações que a favorecem. E só. Elas não são,

\footnotetext{
42 A Política Nacional de Enfrentamento à Violência contra as Mulheres tem por finalidade estabelecer conceitos, princípios, diretrizes e ações de prevenção e combate à violência contra as mulheres, assim como de assistência e garantia de direitos às mulheres em situação de violência, conforme normas e instrumentos internacionais de direitos humanos e legislação nacional.

43 BRASIL. Política Nacional de Enfrentamento à Violência Contra as Mulheres. Brasília: Secretaria Nacional de Enfrentamento à Violência contra as Mulheres Secretaria de Políticas para as Mulheres, 2011, p. 27. Disponível em: <http://www.spm.gov.br/sobre/publicacoes/publicacoes/2011/politica-nacional>. Acesso em: 22 nov. 2016.

44 BRASIL. Ministério da Justiça. Secretaria de Assuntos Legislativos. Violência contra a mulher e as práticas institucionais. Brasília: Ministério da Justiça, 2015, p. 20.
} 
necessariamente, preparatórias de qualquer ação judicial. Elas não visam processos, mas pessoas. ${ }^{45}$

As Medidas Protetivas de Urgência estão sendo incorporadas a serviço do modelo de justiça consensual, considerada a sua mera concessão como solução definitiva do conflito, sem a garantia e o acompanhamento de sua efetividade. O seu deferimento, nessa via, demonstra uma espécie de “compensação" pela violência sofrida, sem preocupação com o empoderamento da vítima e suas reais condições para interromper com o ciclo de ameaças e agressões. Negligenciadas, portanto, a proteção e a assistência legalmente previstas à vítima, bem como a persecução criminal e a punição dos crimes preconizados pela lei. ${ }^{46}$

Entre as usuárias entrevistadas, 22\% ressaltaram que procuraram um familiar antes de recorrer à justiça e $28 \%$ alegaram ter procurado outras pessoas como vizinhos e amigos. De um modo geral a solução judicial é como regra, a ultima ratio a ser considerada nas relações sociais. Evidenciando-se que para uma parcela das entrevistadas a ajuda judicial foi procurada como um último recurso, já que a mulher em situação de violência na maioria dos casos recorre à Justiça apenas quando não há outra opção menos invasiva disponível.

Além disso, uma considerável parcela dessas mulheres não possui conhecimentos do que é processar e julgar criminalmente; não há informação clara acerca do fluxo da Justiça Criminal, observou-se que, muitas assistidas não sabem "o que pode acontecer". E, mesmo quando o descobrem, constata-se, o anseio das mulheres por um modo eficaz de lidar com tal violência sem que seja preciso a aplicação de uma pena privativa de liberdade ou que não tenha que aguardar tanto tempo uma decisão.

Neste contexto, 31\% das mulheres acreditam que a melhor solução para o seu conflito de violência doméstica e familiar seria aplicar a pena e prender o agressor, seguidos de $22 \%$ que acreditam que a melhor solução seria resolver o problema com psicólogos e/ou assistentes sociais e outros $22 \%$ das entrevistadas acreditam que o agressor deve apenas frequentar grupos para se conscientizar. Mas nem todas estão satisfeitas com as medidas que têm sido aplicadas (ou disponíveis) pelo Judiciário, assim, uma das entrevistadas manifestou sua opinião:

Começaria pela Medida sendo estendida aos filhos que são vítimas indiretas da violência doméstica. Porque o agressor usa os filhos para continuar com a

\footnotetext{
45 LIMA, Fausto Rodrigues de. Dos procedimentos: arts. 13 a 17. In: CAMPOS, Carmem Hein de (Org.). Lei Maria da Penha comentada em uma perspectiva Jurídico-feminista. Rio de Janeiro: Lumen Juris, 2011, p. 329.

${ }^{46}$ BARRÊTO, L M.; CHAI, C. G. Até onde meter a colher: o problema da (in)execução das medidas protetivas de urgência da Lei Maria da Penha. In: CHAl, C. G. (org.). Republicanismo entre ativismos judiciais e proibição do retrocesso: da proteção às mulheres à saúde pública. Campos dos Goytacazes, RJ: Brasil Multicultural, 2016, p. 28.
} 
violência psicológica, já que a física não consegue mais. Devia ser condenado a pagar pensão e demais tratamentos à vítima de violência. Assim, seria permitido somente visita assistida pra não colocar mais a criança em risco, pois já basta todo o trauma que passou vendo a mãe ser agredida. Caso desobedecesse as restrições, deveria ser preso [sic]. (Entrevistada 02)

Importante ressaltar que recentemente o STJ publicou duas decisões relacionadas à aplicação de penas nos casos de violência doméstica e familiar contra a mulher. A primeira delas, a Súmula 588 estabelece que “a prática de crime ou contravenção penal contra a mulher com violência ou grave ameaça no ambiente doméstico impossibilita a substituição de pena privativa de liberdade por restritiva de direitos". ${ }^{47}$ Portanto, crimes e contravenções cometidos contra mulher no ambiente doméstico e familiar não merecem as medidas despenalizadores da Lei $9.099 / 95$, ficando vedada, ainda, a substituição da pena privativa por restritiva quando praticados com violência ou grave ameaça à pessoa. Já a Súmula 589 do STJ decidiu pela "inaplicabilidade do princípio da insignificância ${ }^{48}$ nos crimes de contravenções penais praticados contra a mulher no âmbito das relações domésticas". ${ }^{49}$ Dessa forma, os delitos praticados com violência contra a mulher, devido à expressiva ofensividade, periculosidade social, reprovabilidade do comportamento e lesão jurídica causada, perdem a característica da bagatela e devem submeter-se ao direito penal. Assim, o STJ e o STF não admitem a aplicação dos princípios da insignificância aos crimes e contravenções praticados com violência ou grave ameaça contra a mulher, no âmbito das relações domésticas, dada a relevância penal da conduta.

Deter o agressor e garantir a segurança pessoal e patrimonial da vítima e seus filhos(as) está a cargo da policia, do juiz e do Ministério Público. Todos devem agir de modo imediato e eficiente. A Lei traz em seu artigo 22, IV uma medida salutar que consiste na restrição ou suspensão das visitas do agressor aos filhos, já que, por ocasião das visitas, podem ocorrer novos atos de violência. De modo que:

\footnotetext{
${ }^{47}$ BRASIL. Superior Tribunal de Justiça. Súmula $n^{\circ}$ 588. A prática de crime ou contravenção penal contra a mulher com violência ou grave ameaça no ambiente doméstico impossibilita a substituição de pena privativa de liberdade por restritiva de direitos. Disponível em: <http://www.stj.jus.br/sites/STJ/default/pt_BR/Comunica\%C3\%A7\%C3\%A3o/noticias/Not\%C3\%ADcias/STJ -edita-seis-novas-s\%C3\%BAmulas>. Acesso em: 03 out. 2017.

48 o princípio da insignificância não tem previsão legal no direito brasileiro. Trata-se de uma criação da doutrina e da jurisprudência. Para a posição majoritária, o princípio da insignificância é uma causa supralegal de exclusão da tipicidade material. Se o fato for penalmente insignificante, significa que não lesou nem causou perigo de lesão ao bem jurídico. Logo, aplica-se o princípio da insignificância e o réu é absolvido por atipicidade material, com fundamento no art. 386, III do CPP.

49 BRASIL. Superior Tribunal de Justiça. Súmula $n^{\circ} 589$. É inaplicável o princípio da insignificância nos crimes ou contravenções penais praticados contra a mulher no âmbito das relações domésticas. Disponível em: <http://www.stj.jus.br/sites/STJ/default/pt_BR/Comunica\%C3\%A7\%C3\%A30/noticias/Not\%C3\%ADcias/ STJ-edita-seis-novas-s\%C3\%BAmulas>. Acesso em: 03 out. 2017.
} 
As crianças que crescem em lares violentos internalizam um conjunto de crenças e valores negativos que abrangem os estereótipos de gênero, as desigualdades entre homem/ mulher, as relações com os outros, bem como a legitimidade do uso da violência como meio de resolução de conflitos, que formam a base do seu comportamento futuro nos relacionamentos. A tendência é que as meninas se identifiquem com o papel materno, adotando comportamentos de submissão, passividade e obediência; e os meninos com o papel paterno, assumindo posições de poder e privilégio. ${ }^{50}$

A Lei 11.340/2006 preceitua que a medida deve ser tomada depois de ouvida a equipe de atendimento multidisciplinar, exigindo-se cautela, visando sempre o melhor interesse das crianças e adolescentes, bem como da vítima. A exposição à violência pode ser prejudicial ao desenvolvimento infantil porque tanto o agressor, quanto a vítima são conhecidos da criança e estão envolvidos emocionalmente com ela.

Em relação ao atendimento prestado pelo Judiciário, 25\% das jurisdicionadas afirma ter sido péssimo, $22 \%$ classificou como ruim e $20 \%$ das mulheres dizem ter sido regular. Uma das entrevistadas relata que:

O meu caso está na justiça há mais de 03 anos e no início não explicaram o que era pra 'mim' fazer. Não vim mais aqui e meu caso ficou 'esquecido', só depois da situação de violência se repetir é que eu precisei voltar aqui e eles foram dar continuidade ao processo [sic]. (Entrevistada 03)

Tal relato faz com que entendamos a importância da capacitação de quem quer que esteja atendendo e assistindo a vítima. 0 respeito ao compromisso com o atendimento à mulher vítima é tão necessário quanto à disponibilidade para uma informação acurada.

Por isso, precisa-se compreender quem é essa mulher, qual a sua história. Não se podem consubstanciar as experiências das vítimas. É necessária uma escuta cautelosa, uma orientação moderada no que foi apresentado pela mulher, como também uma orientação clara e precisa para que a assistida não saia do atendimento com diversos papéis, com vários encaminhamentos e burocracias a cumprir. Sem falar que, tais trâmites geram altos custos nem sempre suportados pelas assistidas.

Humanização, portanto, expecta conexão do conhecimento técnico com a capacidade de perceber o ser humano nas suas diferentes condições. A negligência, discriminação, massificação do atendimento traduz uma forma de violência: a violência institucional.

Por conseguinte, $48 \%$ das mulheres classificam a solução da Justiça como ruim. $37 \%$ acreditam que a solução é boa, mas lenta, no sentido de terem recebido um atendimento

50 SEPÚLVEDA GARCÍA DE LA TORRE, María Ángeles. La violencia de género como causa de maltrato infantil. Cuadernos Médicos Forenses, vol. 12 (43-44), 2006, p. 161. 
condizente com suas expectativas, mas a demora dos processos judiciais serem frustrantes, e por fim, $11 \%$ das participantes dizem que a solução é boa, mas ineficaz, já que receberam um atendimento adequado, no entanto, a resposta judicial não foi suficiente para cessar o conflito existente entre as partes.

Sobre a agilidade dos processos judiciais, $80 \%$ das usuárias relataram que este é o principal elemento que deve ser melhorado no Judiciário. A demora para a obtenção de uma determinação judicial condizente com o que a mulher necessita, acaba produzindo uma percepção de que a Justiça não é eficiente e que a prestação jurisdicional não terá o alcance desejado, causando assim uma sensação de descrença no Poder Judiciário. Uma das usuárias confessa que:

Se eu não fosse obrigada a comparecer às audiências já teria abandonado tudo, hoje é a $4^{\mathrm{a}}$ vez que venho aqui e cancelam a minha audiência, não nos informam nada e demora demais a sair uma solução [sic]. (Entrevistada 04)

0 atendimento foi o segundo elemento mais apontado nos questionários respondidos pelas mulheres entrevistadas, $60 \%$ das usuárias estão descontentes com as idas infrutíferas até a Vara. Além disso, uma escuta sensível e humanizada compreende também a resposta a este estímulo sensorial. Resposta, esta, que se traduz em atenção, acolhimento sem julgamento, aconselhamentos sem imposições, respeito às vontades, encaminhamentos, petições, bem como informações precisas e adequadas ao caso e sobre o caso.

Entre as entrevistadas 54\% responderam que é necessário melhorar o acesso à informação. Já que é de suma importância que as informações passadas às vítimas contemplem todo o seu caso, abrangendo possíveis soluções para a reintegração ou garantia de direitos que também extrapolem a esfera penal, bem como a noção do andamento processual e das eventuais prestações a serem requeridas imediatamente e tomadas, posteriormente, por exemplo, em caso de concessão e descumprimento de uma medida protetiva. De acordo com uma das entrevistadas:

Muitas pessoas que trabalham aqui não fornecem as informações necessárias e não explicam com paciência o que deve ser feito. Também muitos advogados não são sensibilizados com a causa e se a mulher não tiver condições de 'pagar bem' pelo serviço eles não estão 'nem aí' para o caso [sic]. (Entrevistada 05)

A privacidade e a estrutura foram aspectos citados por $42 \%$ das usuárias que precisam esperar do lado de fora da sala de audiências sentadas ao lado de seu agressor, suportando às vezes humilhações e provocações dos familiares do réu. Sem falar do distanciamento do Judiciário tanto geográfico, longe das áreas rurais e periféricas da capital; como institucional, 
no que se referem à linguagem, vestimentas e arquitetura do fórum. Deixando assim, os atores jurídicos cada vez mais afastados dos jurisdicionados. ${ }^{51}$

0 quadro de funcionários foi mencionado por $40 \%$ das entrevistadas como algo que necessita ser ampliado, já que a Lei Maria da Penha (Lei 11.340/06) em seus artigos 29 a $32^{52}$ institui a necessidade de uma equipe multidisciplinar nas Varas de Combate à Violência Doméstica e Familiar Contra a Mulher, trazendo assim mais eficiência aos atendimentos prestados. É notável a falta de profissionais condizente com a demanda, quando uma das usuárias ressalta que:

Eu nunca imaginei passar por uma violência doméstica, acreditava que isso seria algo distante da minha realidade, já que no meu trabalho eu oriento mulheres que sofreram violência em seus lares. Estou pagando tratamento psicológico por conta própria, pois esperei mais de um mês para ser atendida pelo psicólogo da Vara [sic]. (Entrevistada 06)

O horário de atendimento foi criticado por 31\% das jurisdicionadas que precisam faltar no serviço por conta das idas ao Fórum, além do mais, elas possuem uma dupla jornada de trabalho desempenhando outras atividades que demandam seu tempo e atenção, como buscar os filhos na escola, tarefas domésticas, etc.

A Lei Maria da Penha encarna uma proposta de Política Pública em Direitos Humanos que objetiva traçar um caminho a ser seguido pelos poderes públicos em todas as esferas de governo. Por isso, a sua aplicabilidade e a sua eficácia dependem também do Judiciário e de seus atores.

De acordo com os dados levantados, observa-se que o Estado, não é uma instituição indivisível, não possui um discurso unívoco, mas reforça e institucionaliza a violência contra a mulher por meio de discurso dúbio, que tipifica tais condutas como crime, mas também exerce,

\footnotetext{
${ }^{51}$ MASSULA, Letícia. A violência e o acesso das mulheres à justiça: o caminho das pedras ou as pedras do (no) caminho. In: Vinte e cinco anos de respostas brasileiras em violência contra a mulher: alcances e limites. São Paulo: Coletivo Feminista Sexualidade e Saúde, 2006, p. 142.

52 Art. 29. Os Juizados de Violência Doméstica e Familiar contra a Mulher que vierem a ser criados poderão contar com uma equipe de atendimento multidisciplinar, a ser integrada por profissionais especializados nas áreas psicossocial, jurídica e de saúde. Art. 30. Compete à equipe de atendimento multidisciplinar, entre outras atribuições que the forem reservadas pela legislação local, fornecer subsídios por escrito ao juiz, ao Ministério Público e à Defensoria Pública, mediante laudos ou verbalmente em audiência, e desenvolver trabalhos de orientação, encaminhamento, prevenção e outras medidas, voltados para a ofendida, o agressor e os familiares, com especial atenção às crianças e aos adolescentes. Art. 31. Quando a complexidade do caso exigir avaliação mais aprofundada, o juiz poderá determinar a manifestação de profissional especializado, mediante a indicação da equipe de atendimento multidisciplinar. Art. 32. O Poder Judiciário, na elaboração de sua proposta orçamentária, poderá prever recursos para a criação e manutenção da equipe de atendimento multidisciplinar, nos termos da Lei de Diretrizes Orçamentárias. Disponível em: <http://www.planalto.gov.br/ccivil_03/_ato20042006/2006/lei/l11340.htm>. Acesso em: 12 fev. 2017.
} 
por meio da discricionariedade dos agentes de seu aparato policial-judiciário, a tolerância expressa na ausência de apuração e punição dos autores dos crimes, bem como na negligência em relação à garantia da segurança das vítimas. ${ }^{53}$

Sobre o âmbito do direito, além de se ter leis que assegurem o respeito e a autonomia feminina, é de fundamental importância o estudo de uma escuta acolhedora por parte dos órgãos que recebem as vítimas de violência contra a mulher. Por essa razão, é importante que se aprimore e execute programas oficiais e constantes de formação e atualização para os profissionais, como requisito para sua atuação nesta área.

Para, além disso, medidas como a realização de cursos e oficinas em locais como os Centros de Referência, podem ter resultados satisfatórios em todas as esferas de desenvolvimento do empoderamento, oportunizando que a mulher ressignifique suas relações consigo mesma e com os outros e tenha condições de caminhar sozinha para o rompimento do ciclo de violência.

$\mathrm{O}$ atendimento humanizado e a escuta sensível são primordiais para que a mulher possa reconstituir a situação pela qual passa, percebendo-se como vítima de uma agressão, porém sem que isso acentue seu papel de passividade e a paralise. Ao ser capaz de interpretar a violência sofrida como violação a direitos que titulariza, ao colocar-se na posição de sujeito e não mais de objeto da relação conflituosa, portanto, é possível que a mulher se sinta apta a recorrer aos meios disponíveis para romper com este ciclo.

\section{CONCLUSÃO}

Durante a pesquisa de campo observou-se uma falta de receptividade às pesquisas empíricas. Dificuldades intransponíveis institucionais, variando de pautas excessivas e inviabilidade de agenda. Atualmente, a unidade jurisdicional conta com um acervo de cerca de 7.343 processos. Em consequência, houve muitas idas infrutíferas à Vara Especial de Combate à Violência Doméstica e Familiar de São Luís-MA.

Infelizmente a violência de gênero é a raiz de outras formas de violência, manifestandose até mesmo nas Instituições e organizações da sociedade, tanto aquelas privadas quanto públicas.

53 BARRÊTO, L M.; CHAI, C. G. Até onde meter a colher: o problema da (in)execução das medidas protetivas de urgência da Lei Maria da Penha. In: CHAl, C. G. (org.). Republicanismo entre ativismos judiciais e proibição do retrocesso: da proteção às mulheres à saúde pública. Campos dos Goytacazes, RJ: Brasil Multicultural, 2016, p. 18. 
Dessa forma, o número de mulheres entrevistadas ainda é insuficiente para determinar qual o grau de violência institucional é latente e presente no sistema judicial ofertado às mulheres em situação de violência doméstica e familiar de São Luís, além de entender em que nível essa espécie de violência prejudica o acesso à Justiça e influencia no tratamento institucional e no oferecimento de uma solução adequada às partes. Todavia, pelas narrativas coletadas e analisadas através da metodologia científica de análise de conteúdo, consegue-se realizar uma radiografia prévia da violência institucional no seio do poder judiciário e, de modo pontual, em correlatas unidades jurisdicionais e respectivos órgãos.

Dito isto, é perceptível que entre a maioria das entrevistadas prevalece um sentimento de frustração com o atendimento apresentado pelas instituições em que procurou ajuda, evidenciando-se que existe uma escassez do trabalho em Rede, como uma desarticulada funcionalidade, uma dificuldade em relação ao cumprimento de medidas protetivas por parte do agressor, sem falar no grande número de demandas em contrapartida à falta de espaço para a prestação de um atendimento humanizado.

Problemas estes que poderiam ser solucionados com medidas para o aprimoramento do atendimento, tais como: ampliação e melhoria dos espaços e condições de atendimento; aumento do número de profissionais e a oferta de capacitações para uma atuação eficaz desde o acolhimento, e acessibilidade; comunicação precisa e controlada entre os órgãos; sistematização das informações; e, trabalhos no sentido de empoderar a mulher.

Portanto, diante da vulnerabilidade da mulher vítima de violência doméstica, é necessário que o Estado atue na real implementação dos instrumentos processuais previstos pela Lei 11.340/2006 e de políticas públicas de gênero para o adequado amparo e proteção da mulher, a fim de prevenir, desestimular e erradicar uma das formas mais cruéis de violência, que é a doméstica e familiar contra a mulher.

\section{REFERÊNCIAS}

AGENDE - Ações em Gênero e Cidadania e Desenvolvimento. 10 anos da adoção da Convenção Interamericana para Prevenir, Punir e Erradicar a Violência contra a Mulher / Convenção de Belém do Pará - AGENDE / Brasília, Junho de 2004.

ALMEIDA, Suely Souza de. (Org.). Violência de gênero e políticas públicas. Rio de Janeiro: UFRJ, 2007.

ANDREOTTI, C. Enfrentamento da revitimização: a escuta de crianças vítimas de violência sexual. São Paulo: Casa do Psicólogo, 2012. 
BARRÊTO, L M.; CHAI, C. G. Até onde meter a colher: o problema da (in)execução das medidas protetivas de urgência da Lei Maria da Penha. In: CHAI, C. G. (org.). Republicanismo entre ativismos judiciais e proibição do retrocesso: da proteção às mulheres à saúde pública. Campos dos Goytacazes, RJ: Brasil Multicultural, 2016.

BRASIL. Lei n. 11.340, de 07 de agosto de 2006. Cria mecanismos para coibir a violência doméstica e familiar contra a mulher, nos termos do $\S 8^{\circ}$ do art. 226 da Constituição Federal, da Convenção sobre a Eliminação de Todas as Formas de Discriminação contra as Mulheres e da Convenção Interamericana para Prevenir, Punir e Erradicar a Violência contra a Mulher; dispõe sobre a criação dos Juizados de Violência Doméstica e Familiar contra a Mulher; altera o Código de Processo Penal, o Código Penal e a Lei de Execução Penal; e dá outras providências. Diário Oficial da União: Poder Legislativo, Brasília, DF. Disponível em: <http://www.planalto.gov.br/ccivil_03/_ato2004-2006/2006/lei/l11340.htm>. Acesso em: 10 nov. 2016.

BRASIL. Ministério da Saúde. Violência Intrafamiliar - Orientações para a Prática em Serviço/Cadernos de Atenção Básica - nº 08. Brasília - DF, 2003.

BRASIL. Ministério da Justiça e Cidadania. Balanço Ligue 180. Brasília: Secretaria de Política para as Mulheres, 2016. Disponível em: <http://www.spm.gov.br/balanco180_2016-3.pdf >. Acesso em: 12 nov. 2016.

BRASIL. Ministério da Justiça. Secretaria de Assuntos Legislativos. Violência contra a mulher e as práticas institucionais. Brasília: Ministério da Justiça, 2015.

BRASIL. Política Nacional de Enfrentamento à Violência Contra as Mulheres. Brasília: Secretaria Nacional de Enfrentamento à Violência contra as Mulheres Secretaria de Políticas para as Mulheres, 2011. Disponível em:

<http://www.spm.gov.br/sobre/publicacoes/publicacoes/2011/politica-nacional>. Acesso em: 22 nov. 2016.

BRASIL. Superior Tribunal de Justiça. Súmula $n^{\circ}$ 588. A prática de crime ou contravenção penal contra a mulher com violência ou grave ameaça no ambiente doméstico impossibilita a substituição de pena privativa de liberdade por restritiva de direitos. Disponível em: <http://www.stj.jus.br/sites/STJ/default/pt_BR/Comunica\%C3\%A7\%C3\%A30/noticias/Not\%C3\%A Dcias/STJ-edita-seis-novas-s\%C3\%BAmulas>. Acesso em: 03 out. 2017.

BRASIL. Superior Tribunal de Justiça. Súmula $n^{\circ}$ 589. É inaplicável o princípio da insignificância nos crimes ou contravenções penais praticados contra a mulher no âmbito das relações domésticas. Disponível em: <http://www.stj.jus.br/sites/STJ/default/pt_BR/Comunica\%C3\%A7\%C3\%A30/noticias/Not\%C3\%A Dcias/STJ-edita-seis-novas-s\%C3\%BAmulas>. Acesso em: 03 out. 2017.

BOURDIEU, Pierre. A dominação masculina. Rio de Janeiro: Bertrand Brasil, 2011.

BUTLER, Judith. Problemas de gênero: Feminismo e subversão da identidade. Rio de Janeiro: Civilização Brasileira, 2010. 
COSTA, Ana Alice. Gênero, poder e empoderamento das mulheres. Salvador: NEIM/UFBA, 1999.

FERREIRA, Maria Mary. Representação feminina e construção da democracia no Brasil. Coimbra: CES, 2004. Disponível em:

<http://www.ces.uc.pt/lab2004/inscricao/pdfs/painel29/MAryFerreira.pdf>. Acesso em: 29 jan. 2017.

GOFFMANN, Erving. Das Arrangement der Geschlechter. Frankfurt/M., 1994 [1977]. p. 105-158.

INSTITUTO DE PESQUISA ECONÔMICA APLICADA (IPEA). Retrato das desigualdades de gênero e raça. Brasília: Ipea, 2011. Disponível em: <http://www.ipea.gov.br/retrato/pdf/revista.pdf>. Acesso em: 25 jan. 2017.

LIMA, Fausto Rodrigues de. Dos procedimentos: arts. 13 a 17. In: CAMPOS, Carmem Hein de (Org.). Lei Maria da Penha comentada em uma perspectiva Jurídico-feminista. Rio de Janeiro: Lumen Juris, 2011.

MASSULA, Letícia. A violência e o acesso das mulheres à justiça: o caminho das pedras ou as pedras do (no) caminho. In: Vinte e cinco anos de respostas brasileiras em violência contra a mulher: alcances e limites. São Paulo: Coletivo Feminista Sexualidade e Saúde, 2006.

MOJAB, Shahrzad (ED.). Marxism and Feminism. Zed Books London, 2015.

NOVELLINO, M. S. F. Os estudos sobre feminização da pobreza e políticas públicas para mulheres. In: XXVIII Encontro Anual da ANPOCS, 2004, Caxambu. XXVIIII Encontro Anual da ANPOCS, 2004. v. 1. Disponível em: <https://www.anpocs.com/index.php/papers-28encontro/st-5/st23-2/4076-mnovellino-os-estudos/file>. Acesso em: 10 jan. 2017.

PORTELLA, A. P.; GOUVEIA, T. Ideias e dinâmicas para trabalhar com gênero. Recife: SOS Corpo, Gênero e Cidadania, 1999.

RADBRUCH, Gustav. Introdução à Ciência do Direito. São Paulo: Martins Fontes, 1999, pp. 146 147.

SAFFIOTI, Heleieth I. B.; ALMEIDA, Suely Souza de. Violência de gênero: poder e impotência. Rio de Janeiro: Revinter, 1995.

SAFFIOTI, Heleieth I. B. Já se mete a colher em briga de marido e mulher. São Paulo em Perspectiva. A violência disseminada. São Paulo, vol. 13, n. 04, p. 82-91, out./dez. 1999. Disponível em: $<$ http: / / www.scielo.br/scielo.php?pid=S0102-

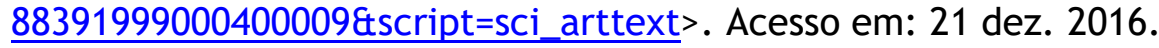

SAFFIOTI, Heleieth I. B. Gênero, patriarcado, violência. São Paulo: Fundação Perseu Abramo, 2004.

SANTOS, B. S. Os Tribunais nas Sociedades Contemporâneas: o caso português, Porto: Afrontamento, 1996. 
SCOTT, Joan. Gênero: uma categoria útil para análise histórica. Tradução: Christine Rufino Dabat; Maria Betânia Ávila. Texto original: Joan Scott - Gender: auseful

Category of historical analyses. Gender and the politics of history. New York: Columbia University Press, 1989.

SEPÚLVEDA GARCÍA DE LA TORRE, María Ángeles. La violencia de género como causa de maltrato infantil. Cuadernos Médicos Forenses, vol. 12 (43-44): pág. 149-164, 2006.

TAQUETTE, Stella (org.). Mulher adolescente/jovem em situação de violência. Brasília: Secretaria Especial de Políticas para as Mulheres, 2007.

WAISELFISZ, Julio Jacobo. Mapa da Violência 2015: Homicídio de mulheres no Brasil. Brasília: Secretaria Especial de Políticas para as Mulheres, 2015. Disponível em: <https://www.mapadaviolencia.org.br/pdf2015/MapaViolencia_2015_mulheres.pdf>. Acesso em: 03 fev. 2017.

WOLFF, L. R.; WALDOW, V. R. Violência consentida: mulheres em trabalho de parto e parto. Saúde e Sociedade, São Paulo, v. 17, n. 3, p. 138-151, set. 2008.

\section{COMO FAZER A REFERÊNCIA DO ARTIGO (ABNT):}

CHAI, Cássius Guimarães; SANTOS, Jéssica Pereira dos; CHAVES, Denisson Gonçalves. Violência institucional contra a mulher: o Poder Judiciário, de pretenso protetor a efetivo agressor. Revista Eletrônica do Curso de Direito da UFSM, Santa Maria, RS, v. 13, n. 2, p. 640-665, ago. 2018. ISSN 1981-3694. Disponível em: < https://periodicos.ufsm.br/revistadireito/article/view/29538 >. Acesso em: dia mês. ano. doi: http://dx.doi.org/10.5902/1981369429538 . 